\title{
Laboratory investigations on the efficacy of hydrogen peroxide against the salmon louse Lepeophtheirus salmonis and its toxicological and histopathological effects on Atlantic salmon Salmo salar and chinook salmon Oncorhynchus tshawytscha
}

\author{
S. C. Johnson ${ }^{1,2}$, J. M. Constible ${ }^{1}$, J. Richard ${ }^{1}$ \\ ${ }^{1}$ Department of Fisheries and Oceans, Biological Sciences Branch, Pacific Biological Station, Nanaimo, British Columbia, \\ Canada V9R 5K6 \\ ${ }^{2}$ Department of Zoology, University of British Columbia, Vancouver, British Columbia, Canada V6T 2A9
}

\begin{abstract}
The efficacy of hydrogen peroxide against the common salmon louse Lepeophtheirus salmonis, and its toxicity to Atlantic (Salmo salar) and chinook (Oncorhynchus tshawytscha) salmon, were investigated under laboratory conditions. Twenty minute bath treatments of $1.5 \mathrm{~g} \mathrm{I}^{-1}$ hydrogen peroxide at $11^{\circ} \mathrm{C}$ effectively dislodged approximately $80 \%$ of the preadult and adult stages of $L$. salmonis, but had no significant effect on the intensity of infection with the attached chalimus stages. More than $96 \%$ of the chalimus larvae and $84 \%$ of the preadults and adults recovered after a 20 min hydrogen peroxide treatment at concentrations of 1.0 to $2.0 \mathrm{~g} \mathrm{t}^{-1}$ at $11{ }^{\circ} \mathrm{C}$. Atlantic salmon were less sensitive to hydrogen peroxide than chinook salmon. The toxicity to both salmon species increased with increasing water temperatures, concentration, and exposure time. Histological sections of gills revealed extensive epithelial lifting and necrosis in those chinook and Atlantic salmon that experienced acute toxicity.
\end{abstract}

KEY WORDS: Hydrogen peroxide - Lepeophtheirus salmonis - Lice - Oncorhynchus tshawytscha Parasite control S Salmo salar. Toxicity

\section{INTRODUCTION}

Lepeophtheirus salmonis is one of several species of marine parasitic copepods that commonly infect, and can cause serious disease in, sea-farmed salmonids (Brandal \& Egidius 1979, Wootten et al. 1982, Pike 1989, Johnson \& Kent 1992). Of these species, collectively referred to as sea lice, $L$. salmonis is the most important species with respect to disease (Wootten et al. 1982, Pike 1989, Johnson \& Kent 1992). All species of sea lice have a direct life cycle consisting of 5 phases and 10 stages. These include 2 free-swimming naupliar stages, 1 free-swimming infectious copepodid stage, 4 attached chalimus stages, 2 preadult stages and an adult stage (Johnson \& Albright 1991).
Currently, epizootics of sea lice on farmed salmonids in Europe are treated by bath treatments with dichlorvos, which is the active ingredient in 'Nuvan $500 \mathrm{EC}^{\prime}$ or 'Aquaguard' (Grave et al. 1991a, b, Jackson \& Costello 1992, Roth et al. 1993). Development of alternative treatment methods for the control of sea lice is a priority as current treatments are labor-intensive, highly stressful to the fish, and have potential environmental risks. In addition, some populations of Lepeophtheirus salmonis are reported to be developing resistance to these chemicals (Jones et al. 1992)

Hydrogen peroxide has long been recognized as a bath treatment for ectoparasites of fishes (reviewed in Schäperclaus 1989; Kabata 1985). Currently, hydrogen peroxide is used in Norway, the Faroe Islands and 
Scotland as an alternative bath treatment for sea lice (Bruno 1992, Thomassen 1993). Thomassen (1993) reports that bath treatments of hydrogen peroxide at a concentration of $1.5 \mathrm{~g} \mathrm{l}^{-1}$ for 20 min effectively removes from 85 to $100 \%$ of the preadult and adult stages of sea lice without toxicity to Atlantic salmon.

This aim of this study was to investigate the efficacy of hydrogen peroxide for the control of the salmon louse Lepeophtheirus salmonis, its toxicity to chinook and Atlantic salmon, and its histopathological effects on the gills.

\section{MATERIALS AND METHODS}

Hydrogen peroxide solutions. Iyydrogen peroxide was obtained from BDH. Inc, as stabilized solutions of approximately $35 \%$ or approximately $50 \%$ w/v. Hydrogen peroxide treatment solutions were prepared by mixing stock solutions with sand-filtered seawater of various temperatures and salinities of 28.0 to $30.0 \%$. Hydrogen peroxide concentrations of the stock solutions and treatment solutions were checked by a permanganate titration method (modified from Vosel 1965). Assayed concentrations of the treatment solutions were generally within $5 \%$ of the targeted concentrations (see Tables $1 \& 2$ ). The concentrations referred to in the text are the targeted concentrations.

Efficacy trials. Naive chinook (Oncorhynchus tshawytscha) and Atlantic (Salmo salar) salmon were infected with Lepeophtheirus salmonis in the laboratory. Ovigerous L. salmonis were collected from wild chinook and chum (Oncorhynchus keta) salmon from the Strait of Georgia, British Columbia, Canada. Rearing of the infectious copepodid stage and the infection of the fish followed the methods given by Johnson \& Albright (1991).

The efficacy of hydrogen peroxide against chalimus larvae on laboratory infected chinook $(n=50), 12.3$ to $18.8 \mathrm{~cm}$ fork length and 19.9 to $49.3 \mathrm{~g}$ wet weight, and Atlantic salmon $(\mathrm{n}=50), 10.6$ to $13.9 \mathrm{~cm}$ fork length and 18.3 to $36.6 \mathrm{~g}$ wet weight, was investigated in 2 separate trials. The number of chalimus larvae was determined prior to treatment on 10 fish of each species. One-half of the remaining fish of each species were immersed for $20 \mathrm{~min}$ in a $1.5 \mathrm{~g} \mathrm{l}^{-1}$ solution of hydrogen peroxide in seawater at $11^{\circ} \mathrm{C}$, and then returned to their respective tanks. The remaining fish were handled in a similar manner but not exposed to hydrogen peroxide, and then returned to their respective tanks to serve as controls. The number of copepods on the control and treated groups was determined at $1 \mathrm{wk}$ posttreatment.

The efficacy of hydrogen peroxide against preadults and adults on Atlantic salmon, 15.1 to $25.7 \mathrm{~cm}$ fork length and 46.3 to $176.1 \mathrm{~g}$ wet weight, was determined after a 20 min immersion in a $1.5 \mathrm{~g} \mathrm{l}^{-1}$ solution of hydrogen peroxide in ambient seawater. The number of copepods was determined on 10 fish prior to treatment and 15 fish immediately after treatment. Copepods that became dislodged during treatment were collected, transferred to fresh flowing seawater, and examined after $36 \mathrm{~h}$ to see if they survived.

Toxicity to chalimus, preadult, and adult stages. Fins with attached chalimus larvae were removed from laboratory infected chinook and Atlantic salmon. Preadults and adults were collected from sea-farmed chinook and Atlantic salmon. Groups of 30 to 42 chalimus larvae (attached to fins) or 12 to 20 preadults and adults were placed in Nitex mesh containers and exposed at $11^{\circ} \mathrm{C}$ io hyuluyen peroxide at various concentrations and durations (Table 1). After exposure, the containers were transferred to fresh running seawater of ambient temperature $\left(9.9\right.$ to $\left.10.1^{\circ} \mathrm{C}\right)$ and salinity. Mortalities in each treatment group were determined after $24 \mathrm{~h}$. Copepods were classified as dead if they failed to respond to mechanical stimulation.

Table 1. Lepeophtheirus salmonis. Survival of chalimus, preadult, and adult stages exposed to hydrogen peroxide baths of different concentrations for different durations. After treatment copepods were transferred to ambient flowing seawater for $24 \mathrm{~h}$ before mortality was assessed. nd: not determined

\begin{tabular}{|c|c|c|c|}
\hline Treatment & $\begin{array}{l}\text { Hydrogen } \\
\text { peroxide } \\
\text { concentration } \\
\text { (start/end) }\end{array}$ & $\begin{array}{l}\text { Chalimus } \\
\text { survival } \\
\text { (24h) }\end{array}$ & $\begin{array}{l}\text { Preadult } \\
\text { and adult } \\
\text { survival } \\
(24 \mathrm{~h})\end{array}$ \\
\hline Control trial $1,11.0^{\circ} \mathrm{C}$ & 0 & $\begin{array}{c}27 / 31 \\
(87.1 \%)\end{array}$ & $\begin{array}{c}13 / 13 \\
(100 \%)\end{array}$ \\
\hline $1.0 \mathrm{~g} \mathrm{l}^{-1}, 20 \mathrm{~min}, 11.0^{\circ} \mathrm{C}$ & $0.97 /$ nd & $\begin{array}{c}31 / 31 \\
(100 \%)\end{array}$ & $\begin{array}{c}12 / 12 \\
(100 \%)\end{array}$ \\
\hline \multicolumn{4}{|l|}{$1.5 \mathrm{~g} \mathrm{l}^{-1}, 20 \mathrm{~min}, 11.0^{\circ} \mathrm{C}$} \\
\hline Trial 1 & $1.50 / 1.46$ & $\begin{array}{c}29 / 30 \\
(96.7 \%)\end{array}$ & $\begin{array}{c}11 / 13 \\
(84.6 \%)\end{array}$ \\
\hline Trial 2 & $1.44 / \mathrm{nd}$ & nd & $\begin{array}{c}18 / 20 \\
(90.0 \%)\end{array}$ \\
\hline \multicolumn{4}{|l|}{$1.5 \mathrm{~g} \mathrm{l}^{-1}, 40 \mathrm{~min}, 11.0^{\circ} \mathrm{C}$} \\
\hline Trial 1 & $1.50 / 1.46$ & $\begin{array}{c}30 / 31 \\
(96.8 \%)\end{array}$ & $\begin{array}{c}11 / 14 \\
(78.6 \%)\end{array}$ \\
\hline Trial 2 & $1.44 / \mathrm{nd}$ & nd & $\begin{array}{c}9 / 20 \\
(45.0 \%)\end{array}$ \\
\hline $2.0 \mathrm{~g} \mathrm{l}^{-1}, 20 \mathrm{~min}, 11.0^{\circ} \mathrm{C}$ & C $1.93 / \mathrm{nd}$ & $\begin{array}{c}32 / 33 \\
(97.0 \%)\end{array}$ & $\begin{array}{c}12 / 12 \\
(100 \%)\end{array}$ \\
\hline Controls, $11.0^{\circ} \mathrm{C}^{\mathrm{a}}$ & 0 & $\begin{array}{c}31 / 33 \\
(93.9 \%)\end{array}$ & $\begin{array}{c}20 / 20 \\
(100 \%)\end{array}$ \\
\hline $3.0 \mathrm{~g} \mathrm{l}^{-1} .20 \mathrm{~min}, 11.0^{\circ} \mathrm{C}$ & $\begin{array}{l}3.2 / 3.2^{b} \\
2.92 / n d^{c}\end{array}$ & $\begin{array}{c}34 / 42 \\
(81.0 \%)\end{array}$ & $\begin{array}{c}6 / 19 \\
(31.6 \%)\end{array}$ \\
\hline $4.0 \mathrm{~g} \mathrm{l}^{-1}, 20 \mathrm{~min}, 11.0^{\circ} \mathrm{C}$ & $\begin{array}{l}=4.47 / \mathrm{nd}^{\mathrm{b}} \\
3.90 / \mathrm{nd}^{\mathrm{c}}\end{array}$ & $\begin{array}{c}20 / 34 \\
(58.8 \%)\end{array}$ & $\begin{array}{c}4 / 18 \\
(22.2 \%)\end{array}$ \\
\hline \multicolumn{4}{|c|}{$\begin{array}{l}\text { C Controls for Trial } 2 \text { and the } 3.0 \text { and } 4.0 \mathrm{~g}^{-1} \text { treatments } \\
\text { Assayed level lor chalimus trial } \\
{ }^{\circ} \text { Assayed level for preadult and adult trial }\end{array}$} \\
\hline
\end{tabular}


Toxicity to sea lice eggs. Groups of 7 ovigerous females collected from sea-farmed chinook salmon were placed in individual Nitex mesh containers and exposed to $1.5 \mathrm{~g} \mathrm{l}^{-1}$ hydrogen peroxide for either 20 or 40 min. After exposure the containers were transferred to fresh running seawater and the hatching success of the eggs was monitored. A group of 7 ovigerous females, handled in a similar manner, but not exposed to hydrogen peroxide, was used as a control.

Toxicity to salmon and histopathological effects on gills. Atlantic salmon, 11.7 to $18.2 \mathrm{~cm}$ fork length and 15.1 to $56.6 \mathrm{~g}$ wet weight, and chinook salmon, 9.5 to $16.7 \mathrm{~cm}$ fork length and 11.4 to $48.4 \mathrm{~g}$, were used to investigate the toxicity and histopathological effects on the gills of hydrogen peroxide. Each species was divided into 4 groups of 10 to 20 fish (Table 2); 3 groups received one each of: a $20 \mathrm{~min}$ immersion in $60 \mathrm{l}$ of $1.5 \mathrm{~g} \mathrm{l}^{-1}$ hydrogen peroxide in $11^{\circ} \mathrm{C}$ seawater, a 40 min immersion in $60 \mathrm{l}$ of $1.5 \mathrm{~g} \mathrm{l}^{-1}$ hydrogen peroxide in $11^{\circ} \mathrm{C}$ seawater, or a $20 \mathrm{~min}$ immersion in $60 \mathrm{l}$ of $3.0 \mathrm{~g} \mathrm{l}^{-1}$ hydrogen peroxide in $11^{\circ} \mathrm{C}$ seawater. One group handled in a manner similar to the treated groups, but not exposed to hydrogen peroxide, was used as a control. After exposure, all groups were transferred to $40 \mathrm{l}$ tanks supplied with flowing seawater of ambient temperature $\left(8.5\right.$ to $11.1^{\circ} \mathrm{C}$ ) and salinity (28 to $30 \%$ ). Mortalities were monitored over a $10 \mathrm{~d}$ period.

To determine the toxicity of hydrogen peroxide at higher temperatures, groups of 20 to 42 chinook and 10 to 26 Atlantic salmon (Table 2) were transferred to $200 \mathrm{ltanks}$ and acclimated for $1 \mathrm{wk}$ to temperatures of 14 and $18{ }^{\circ} \mathrm{C}$. One-half of these fish were immersed in $40 \mathrm{l}$ of $1.5 \mathrm{~g} \mathrm{l}^{-1}$ hydrogen peroxide for $20 \mathrm{~min}$ at their respective temperatures and then returned to their tanks. The remaining fish were handled in a similar manner, adipose fin clipped, and then returned to their respective tanks to serve as controls.

Water temperatures were monitored during the treatments and samples of the treatment solutions were taken for determination of their hydrogen peroxide concentrations.

Gill samples from both species were collected at 1, 3, and $10 \mathrm{~d}$ posttreatment from fish that were treated at the same time and in the same manner as the control and treatment groups. Gill samples were collected from moribund fish in treatment groups with poor survival over the first $6 \mathrm{~h}$ posttreatment. Gill samples were fixed for light microscopy in Davidson's solution or $2.5 \%$ glutaraldehyde to which $2 \% \mathrm{w} / \mathrm{v}$ Alcian blue was added to preserve the mucus coating of the gills (Powell et al. 1992). Tissues were dehydrated through to $100 \%$ alcohol, wax-embedded, and cut to a thickness of $5 \mu \mathrm{m}$ and stained with hematoxylin and eosin.

Statistical analysis. Copepod numbers were standardized to an average fish weight for each species to compensate for differences in size among hosts. Intensity data were $\log (x+1)$ transformed to normalize their distribution, and differences in copepodid intensity (number of parasites per infected host) investigated by $t$-tests. Survival of treated copepods and fish was compared across peroxide doses using G-tests (Sokal \& Rohlf 1981).

\section{RESULTS}

\section{Efficacy trials}

Pretreatment and $7 \mathrm{~d}$ posttreatment intensities of Lepeophtheirus salmonis chalimus and early preadult stages on chinook and Atlantic salmon treated with $1.5 \mathrm{~g} \mathrm{I}^{-1}$ hydrogen peroxide for $20 \mathrm{~min}$ are given in Fig. 1. For both salmon species there was no significant difference in copepod intensity between the pretreatment samples and both the control and treated groups at $7 \mathrm{~d}$ posttreatment, or between the control and treated groups at $7 \mathrm{~d}$ posttreatment ( $t$-test; $p>0.05$ ). Copepods removed from the treated groups at $7 \mathrm{~d}$ posttreatment appeared as active as those from the controls.

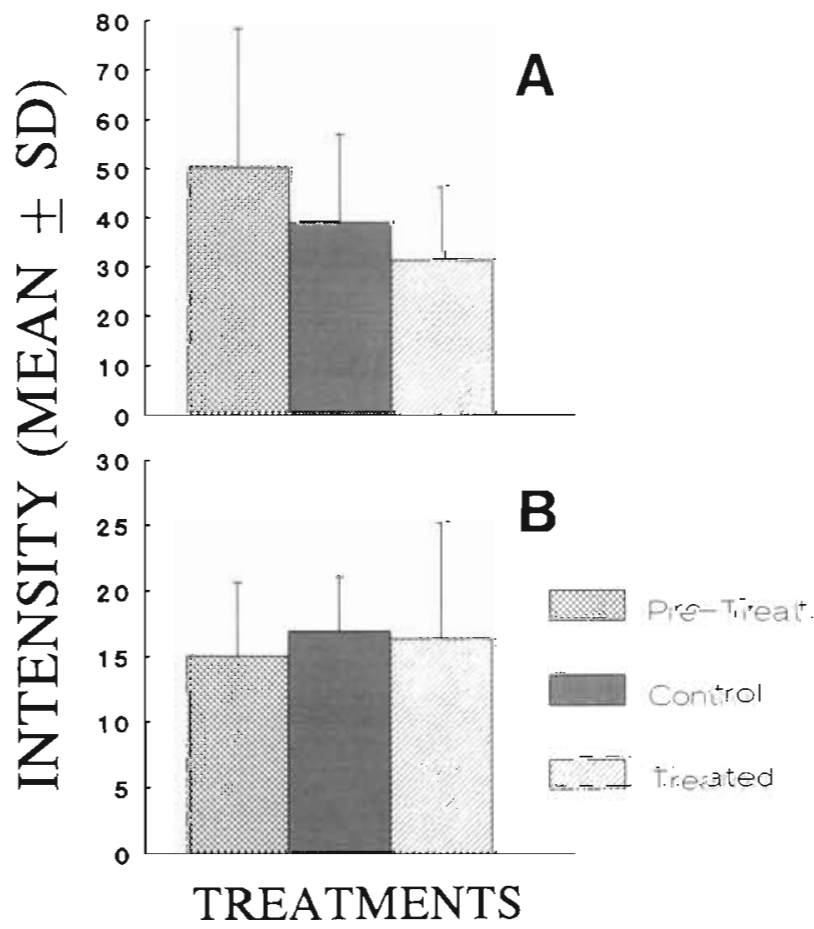

Fig. 1. Lepeophtheirus salmonis infecting Salmo salar and Oncorhynchus tshawytscha. Mean (+SD) intensity of chalimus larvae and early preadults on pretreatment and $7 \mathrm{~d}$ posttreatment control, and hydrogen peroxide treated (A) chinook and (B) Atlantic salmon. Fish infected with chalimus larvae were treated with $1.5 \mathrm{~g} \mathrm{l}^{-1}$ hydrogen peroxide in $11^{\circ} \mathrm{C}$ ambient seawater for $20 \mathrm{~min}$. Fish were maintained at 7.1 to $11.3^{\circ} \mathrm{C}$ and ambient salinity ( 29 to $30 \%$ ) 


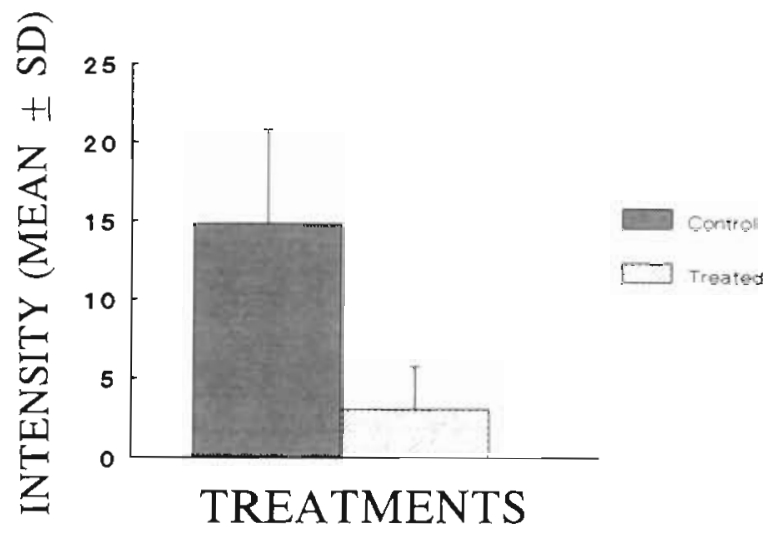

Fig. 2. Lepeophtheirus salmonis infecting Salmo salar. Mean (+SD) intensity of preadults and adults on control and hydrogen peroxide treated Atlantic salmon. Infected fish were treated with $1.5 \mathrm{~g} \mathrm{l}^{-1}$ hydrogen peroxide in $11^{\circ} \mathrm{C}$ ambient seawater for 20 min. Fish were sampled immediately after treatment

The survival of chalimus stages exposed to hydrogen peroxide baths of different concentrations $(1.0,1.5,2.0$, 3.0 or $4.0 \mathrm{~g} \mathrm{l}^{-1}$ ) for $20 \mathrm{~min}$ and $1.5 \mathrm{~g} \mathrm{l}^{-1}$ for $40 \mathrm{~min}$ are given in Table 1. At peroxide levels of 1.0 to $2.0 \mathrm{~g} \mathrm{l}^{-1}$ more than $96 \%$ of the larvae recovered and were actively feeding after $24 \mathrm{~h}$. Chalimus larvae that were treated with 3.0 and $4.0 \mathrm{~g} \mathrm{l}^{-1}$ for $20 \mathrm{~min}$ had lower survival ( 81.0 and 58.8 respectively) and were noticeably less active than the controls.

There was a significant (approximately $80 \%$ ) reduction in the intensity of preadult and adult Lepeophtheirus salmonis on Atlantic salmon given a $20 \mathrm{~min}$ bath treatment of hydrogen peroxide at a concentration of $1.5 \mathrm{~g} \mathrm{l}^{-1}$ ( $t$-test; $\mathrm{p}<0.001$ ) (Fig. 2). During the treatment, copepods were observed to begin falling off the fish within 5 min. The majority of the copepods remaining on the treated fish appeared moribund with little appendage or digestive tract movement. Gas bubbles within the hemocoel were present in $14 \%$ of these 37 copepods. Copepods recovered from the treatment tank also showed little appendage or digestive tract movement. Of 47 copepods collected from the treatment tank and transferred to fresh running seawater, $89 \%$ recovered and were actively swimming or attached to the container after $36 \mathrm{~h}$

High proportions ( 84.6 to $100 \%$ ) of preadult and adult stages recovered after 20 min exposures to hy- drogen peroxide at concentrations of $1.0,1.5$ and $2.0 \mathrm{~g}$ $1^{-1}$ (Table 1). With a longer exposure duration, $1.5 \mathrm{~g} \mathrm{l}^{-1}$ for $40 \mathrm{~min}$ and higher concentrations of peroxide, 3.0 and $4.0 \mathrm{~g} .^{-1}$ for $20 \mathrm{~min}$, survival was reduced. Survival of preadult and adult Lepeophtheirus salmonis was significantly lower $(G$-test $i<0.05)$ than that of the chalimus larvae at these higher concentrations. Exposed preadults and adults were noticeably less active than the controls at all concentrations tested.

During treatment, both species of fish became agitated, ventilation rates increased, and the fish congregated near the water surface. Towards the end of the treatments some jumping activity occurred in the Atlantic salmon. At the end of the treatments, the treated fish of both species were more lethargic than the controis. iNo mortalıties in elther species occurred during the treatments. During the study of the efficacy against chalimus larvae, 2 out of $20(10 \%)$ of the treated chinook salmon, and 1 out of $20(5 \%)$ of the treated Atlantic salmon died over a period of $7 \mathrm{~d}$ posttreatment.

\section{Toxicity to sea lice eggs}

Fifty-seven percent of the egg strings exposed to $1.5 \mathrm{~g} \mathrm{l}^{-1}$ hydrogen peroxide for both 20 and $40 \mathrm{~min}$ failed to develop. Of those which developed, on average $53 \%$ (range 3 to $91 \%$ ) of the eggs hatched, but only a few active nauplii were produced and none molted to the copepodid stage. In the control group, $100 \%$ of the egg strings developed with an average hatching success of $93 \%$ (range 79 to $99 \%$ ). On average, $16 \%$ (range 0 to $47 \%$ ) of the eggs reached the copepodid stage.

\section{Toxicity to salmon and histolopathological effects on gills}

No mortalities of Atlantic or chinook salmon occurred during treatment at any of the concentrations, temperatures, or durations tested. Both species of fish showed some respiratory distress during treatment and were more lethargic than the controls at the end of the treatment. With exception of a $5 \%$ cumulative mortality $(1 / 20 \mathrm{fish})$ in the $11^{\circ} \mathrm{C}$ Atlantic salmon trials, no

Fig. 3. Salmo salar and Oncorhynchus tshawytscha. Effects of hydrogen peroxide exposure on Atlantic and chinook salmon gill morphology. Hematoxylin and eosin stained. (A) Unexposed control Atlantic salmon. Scale bar $=50 \mu \mathrm{m}$. (B) Atlantic salmon treated with $1.5 \mathrm{~g} \mathrm{I}^{-1}$ hydrogen peroxide for $20 \mathrm{~min}$ at $18{ }^{\circ} \mathrm{C}$. Note the cell debris (arrow) within the space formed by the lifted epitheluum, and the congestion of the primary lamellae. Scale bar $=50 \mu \mathrm{m}$. (C) Region of epithelial liftıng in a chinook salmon treated with $1.5 \mathrm{~g} \mathrm{l}^{-1}$ hydrogen peroxide for 20 min at $14^{\circ} \mathrm{C}$. Scale bar $=50 \mu \mathrm{m}$. (D) Chinook salmon treated with $1.5 \mathrm{~g} \mathrm{l^{-1 }}$ hydrogen peroxide for $40 \mathrm{~min}$ at $11^{\circ} \mathrm{C}$. Note the extensive lifting of the gill epithelium and congestion of the primary lamellae (arrow). Scale bar $=50 \mu \mathrm{m}$ 


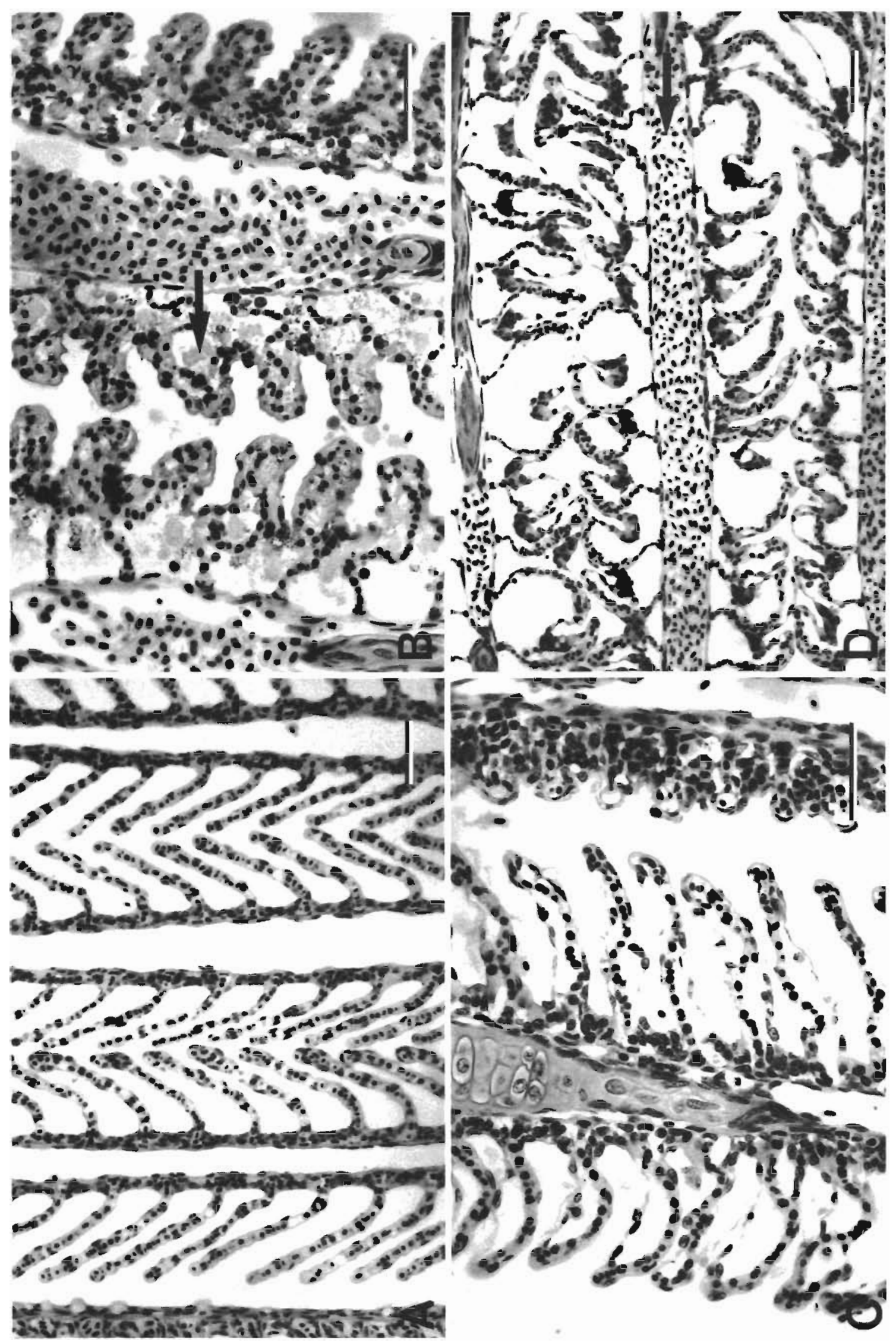


Table 2. Salmo salar and Oncorhynchus tshawytscha. Percent cumulative mortality of hydrogen peroxide treated Atlantic and chinook salmon at 1 and $10 \mathrm{~d}$ posttreatment (dpt). Salmon were treated and maintained at different temperatures. With exception of a $5 \%$ mortality in the $11^{\circ} \mathrm{C}$. Atlantic salmon trials, no mortalities occurred in any of the control groups. nd: not determined

\begin{tabular}{|c|c|c|c|}
\hline \multirow[t]{2}{*}{ Treatment } & \multirow{2}{*}{$\begin{array}{l}\text { Assayed hydrogen } \\
\text { peroxide conc. } \\
\text { (starl/end) }\end{array}$} & \multicolumn{2}{|c|}{$\begin{array}{l}\text { No. dead/total fish } \\
\text { (cum. mort. \%) }\end{array}$} \\
\hline & & $1 \mathrm{dpt}$ & $10 \mathrm{dpt}$ \\
\hline \multicolumn{4}{|l|}{ Atlantic salmon } \\
\hline $1.5 \mathrm{gl}^{-1} .20 \mathrm{~min}, 11.0^{\circ} \mathrm{C}$ & $1.47 / 1.48$ & $\begin{array}{l}0 / 20 \\
(0 \%)\end{array}$ & $\begin{array}{c}2 / 20 \\
(10.0 \%)\end{array}$ \\
\hline $1.5 \mathrm{gl}^{-1} .20 \min 14.0^{\circ} \mathrm{C}$ & $1.51 / 1.49$ & $\begin{array}{c}1 / 13 \\
(7.7 \%)\end{array}$ & $\begin{array}{c}1 / 13 \\
(7.7 \%)\end{array}$ \\
\hline $1.5 \mathrm{gl}^{-1}, 20 \mathrm{~min}, 18.0^{\circ} \mathrm{C}$ & $1.50 / 1.49$ & $\begin{array}{c}5 / 5 \\
(100 \%)\end{array}$ & \\
\hline & & \\
\hline Trial 1 & $1.48 / 1.50$ & $\begin{array}{c}1 / 10 \\
(10.0 \%)\end{array}$ & nd \\
\hline Trial 2 & $1.44 / 1.44$ & $\begin{array}{c}4 / 15 \\
(26.7 \%)\end{array}$ & $\begin{array}{c}4 / 15 \\
(26.7 \%)\end{array}$ \\
\hline $3.0 \mathrm{~g} \mathrm{l}^{-1}, 20 \mathrm{~min}, 11.0^{\circ} \mathrm{C}$ & $2.79 / 2.80$ & $\begin{array}{c}2 / 20 \\
(10.0 \%)\end{array}$ & $\begin{array}{c}2 / 20 \\
(10.0 \%)\end{array}$ \\
\hline \multicolumn{4}{|l|}{ Chinook salmon } \\
\hline $1.5 \mathrm{~g} \mathrm{l}^{-1} .20 \mathrm{~min}, 11.0^{\circ} \mathrm{C}$ & $1.49 / 1.48$ & $\begin{array}{c}1 / 20 \\
(5.0 \%)\end{array}$ & $\begin{array}{c}1 / 20^{a} \\
(5.0 \%)\end{array}$ \\
\hline \multicolumn{4}{|l|}{$1.5 \mathrm{gl}^{-1}, 20 \mathrm{~min}, 14.0^{\circ} \mathrm{C}$} \\
\hline Trial 1 & $1.48 / 1.48$ & $\begin{array}{l}0 / 20 \\
(0 \%)\end{array}$ & $\begin{array}{l}0 / 20 \\
(0 \%)\end{array}$ \\
\hline Trial 2 & $1.49 / \mathrm{nd}$ & $\begin{array}{l}0 / 10 \\
(0 \%)\end{array}$ & $\begin{array}{c}2 / 10 \\
(20.0 \%)\end{array}$ \\
\hline $1.5 \mathrm{~g} \mathrm{l}^{-1}, 20 \mathrm{~min}, 18.0^{\circ} \mathrm{C}$ & $1.72 / 1.72$ & $\begin{array}{c}21 / 21 \\
(100 \%)\end{array}$ & \\
\hline $1.5 \mathrm{~g} \mathrm{l}^{-1} .40 \mathrm{~min}, 11.0^{\circ} \mathrm{C}$ & $1.48 / 1.48$ & $\begin{array}{c}20 / 20 \\
(100 \%)\end{array}$ & \\
\hline $3.0 \mathrm{~g} \mathrm{~J}^{-1}, 20 \mathrm{~min}, 11.0^{\circ} \mathrm{C}$ & $2.91 / 2.91$ & $\begin{array}{c}5 / 20 \\
(25.0 \%)\end{array}$ & nd \\
\hline
\end{tabular}

mortalities occurred in any of the control groups over the $10 \mathrm{~d}$ posttreatment period.

Over the $10 \mathrm{~d}$ posttreatment period there was low mortality $(0$ to $10 \%)$ in the Atlantic salmon groups treated with $1.5 \mathrm{~g} \mathrm{l}^{-1}$ hydrogen peroxide for $20 \mathrm{~min}$ at both 11 and $14^{\circ} \mathrm{C}$, and $3.0 \mathrm{gl}^{-1}$ hydrogen peroxide for $20 \mathrm{~min}$ (Table 2). With exception of 1 fish that had small regions of lamellar epithelial lifting, the gills collected from fish exposed to $1.5 \mathrm{~g} \mathrm{l}{ }^{1}$ 'hydrogen peroxide for $20 \mathrm{~min}$ at $11^{\circ} \mathrm{C}$ showed no pathological changes that could be associated with hydrogen peroxide exposure when compared to the controls (Fig. 3A).

When compared to the controls, most gills of Atlantic salmon treated with $1.5 \mathrm{~g} \mathrm{I}^{-1}$ hydrogen peroxide for 20 min at $14{ }^{\circ} \mathrm{C}$ had small regions where the epithelium had lifted, some congestion of the primary and secondary lamellae, and some clubbing of the secondary lamellae.

Examination of gills from Atlantic salmon treated with $3.0 \mathrm{~g} \mathrm{l}^{-1}$ hydrogen peroxide for $20 \mathrm{~min}$ at $11^{\circ} \mathrm{C}$ revealed extensive epithelial lifting in 1 out of the 5 fish sampled at $1 \mathrm{~d}$ postexposure. The remaining gills generally showed some congestion of the primary and secondary lamellae, and scattered small regions of epithelial lifting and hyperplasia.

Up to $27 \%$ cumulative mortality occurred in Atlantic salmon treated with $1.5 \mathrm{~g}^{-1}$ hydrogen peroxide for 40 min at $11^{\circ} \mathrm{C}$. Examination of the gills of moribund fish revealed extensive lamellar epithelium lifting, and congestion of the primary and secondary lamellae. The remaining gills generally had scattered regions of epithelial lifting and hyperplasia, and some congestion of the priındly and secondary lameỉae.

Within $1 \mathrm{~d}$ posttreatment all Atlantic salmon treated with $1.5 \mathrm{~g}^{-1}$ hydrogen peroxide for $20 \mathrm{~min}$ at $18^{\circ} \mathrm{C}$ were dead. Examination of histological sections of their gills revealed extensive lamellar epithelium lifting, necrotic debris, and congestion of the primary and secondary lamellae (Fig. 3B).

Chinook salmon treated with a hydrogen peroxide at a concentration of $1.5 \mathrm{~g} \mathrm{l}^{-1}$ for $20 \mathrm{~min}$ at $11^{\circ} \mathrm{C}$ had a $5 \%$ cumulative mortality over the $10 \mathrm{~d}$ posttreatment period (Table 2). When compared to the gills of control fish, the gills of treated fish showed no pathological changes that could be associated with hydrogen peroxide exposure.

There were no mortalities in the group treated with $1.5 \mathrm{~g} \mathrm{l}^{-1}$ hydrogen peroxide for $20 \mathrm{~min}$ at $14^{\circ} \mathrm{C}$. With exception of a few small areas of mild epithelial lifting, no pathological changes were observed that could be associated with hydrogen peroxide exposure (Fig. 3C).

By 1 d posttreatment, all chinook salmon treated with $1.5 \mathrm{~g} \mathrm{l}^{-1}$ hydrogen peroxide for $40 \mathrm{~min}$ at $11^{\circ} \mathrm{C}$ or for $20 \mathrm{~min}$ at $18^{\circ} \mathrm{C}$ were dead (Table 2). Examination of the gills of moribund fish collected at 2 to $4 \mathrm{~h}$ posttreatment revealed extensive areas of lamellar epithelium lifting and severe congestion of the primary and secondary lamellae (Fig. 3D). Cell debris were present in the spaces formed by the lifting of the epithelium. Survival of chinook salmon was significantly lower ( $G$-test; $p<0.05$ ) than that of Atlantic salmon in these treatment regimes.

Chinook salmon treated with $3.0 \mathrm{~g}^{-1}$ hydrogen peroxide for $20 \mathrm{~min}$ at $11^{\circ} \mathrm{C}$ had mortality levels of 25 and $30 \%$ at 1 and 3 d posttreatment respectively (Table 2 ). Examination of gill sections at 1 and $3 \mathrm{~d}$ posttreatment revealed 1 out of 20 to show lifting of the lamellar epithelium. When compared to the controls, the remaining gills sections had a higher number of regions where mild epithelial hyperplasia caused the clubbing and or fusion of the secondary lamellae. 


\section{DISCUSSION}

In our study, treatment with hydrogen peroxide at a level of $1.5 \mathrm{~g} \mathrm{l}^{-1}$ for $20 \mathrm{~min}$ at $11^{\circ} \mathrm{C}$ effectively removed approximately $80 \%$ of the preadult and adult stages of Lepeophtheirus salmonis, but had no significant effect on the numbers of attached chalimus larvae. Although not studied, it is likely that hydrogen peroxide would remove a high proportion of copepodid larvae, which are not physically attached to the fish. Thomassen (1993) reported that in field trials, treatments of $1.5 \mathrm{~g}$ $\mathrm{l}^{-1}$ hydrogen peroxide for $20 \mathrm{~min}$ at 8 to $12^{\circ} \mathrm{C}$ effectively removed between 85 and $100 \%$ of the sea lice, including large proportions of chalimus larvae in some trials. At lower water temperatures, a higher level of hydrogen peroxide was reported to be necessary to achieve the same level of efficacy of delousing (Thomassen 1993). The mode of action of hydrogen peroxide against sea lice is unknown. It has been suggested that bubbles which form within the body of sea lice during treatment may result in mechanical paralysis (J. M. Thomassen, Agricultural University of Norway, pers. comm.).

Even at treatment regimes which cause significant mortalities of both chinook and Atlantic salmon, high proportions of the chalimus, preadult and adult stages of Lepeophtheirus salmonis recovered. Because the chalimus larvae are physically attached to the host. they will recover and resume their feeding and development. However, the preadult and adult stages of $L$. salmonis, once removed, are unlikely to reinfect the fish as they generally show little swimming activity and transfer between hosts (Bruno \& Stone 1990). No reinfection of salmon by preadults and adults has been reported following delousing with hydrogen peroxide in Norway (Thomassen 1993).

Providing they have a similar response to hydrogen peroxide, preadult and adult stages of other species of sea lice, such as Caligus clemensi and Caligus elongatus, may be more likely to reinfect the fish after treatment. Reinfection is more likely in these species because their preadult and adult stages are more active swimmers and commonly transfer between hosts (Wootten et al. 1982, Bruno \& Stone 1990, Bron et al. 1993).

In our study, the acute toxicity of both Atlantic and chinook salmon to hydrogen peroxide increased with increased water temperatures and exposure times. For Atlantic salmon, we report $7.7 \%$ mortality at $14{ }^{\circ} \mathrm{C}$ and $100 \%$ at $18^{\circ} \mathrm{C}$ with exposure for $20 \mathrm{~min}$ to hydrogen peroxide at a concentration of $1.5 \mathrm{~g} \mathrm{l}^{-1}$. Thomassen (1993) investigated the toxicity of $30 \mathrm{~min}$ exposures of hydrogen peroxide to Atlantic salmon at various temperatures $\left(6,13\right.$ and $18^{\circ} \mathrm{C}$ ) and peroxide concentrations ( 1.8 to $9.7 \mathrm{~g} \mathrm{l}^{-1}$ ) and reported similar results. In his study, no mortality was reported in Atlantic salmon treated at concentrations of $4.0 \mathrm{~g} \mathrm{l}^{-1}$ or less at $6^{\circ} \mathrm{C}$. Even at higher concentrations $\left(4.0\right.$ to $\left.9.7 \mathrm{~g} \mathrm{l}^{-1}\right)$ at $6^{\circ} \mathrm{C}$, mortalities never exceeded $20 \%$. At $14{ }^{\circ} \mathrm{C}$ mortalities did not exceed $10 \%$ until the concentration exceeded $3.0 \mathrm{~g} \mathrm{l}^{-1}$ when a mortality of $60 \%$ was reported. Although no mortality was reported at a concentration of $1.8 \mathrm{~g} \mathrm{l}^{-1}$, increasing the concentration to $2.0 \mathrm{~g} \mathrm{l}^{-1}$ resulted in approximately $75 \%$ mortality at $18^{\circ} \mathrm{C}$. Innes Taylor \& Ross (1988) reported that fry of Oreochromis niloticus survived for less than $1 \mathrm{~h}$ in solutions of 0.24 to $0.48 \mathrm{~g} \mathrm{l}^{-1}$ hydrogen peroxide at $30^{\circ} \mathrm{C}$. Due to the increased toxicity of hydrogen peroxide at higher temperatures, treatment of Atlantic salmon at temperatures above $14^{\circ} \mathrm{C}$ is not recommended (Thomassen 1993).

It appears that different species of salmon differ in their sensitivity to hydrogen peroxide. We have demonstrated that Atlantic salmon are less sensitive to hydrogen peroxide than chinook salmon. Rainbow trout also appear to be more sensitive to hydrogen peroxide than Atlantic salmon (J. M. Thomassen, Agricultural University of Norway, pers. comm.). The reason for the difference in sensitivity to hydrogen peroxide among these species remains to be determined. These species may differ in the level of catalase activity, and hence their ability to decompose hydrogen peroxide into water and oxygen. If hydrogen peroxide is to become more widely used as a chemotherapeutant in salmonid aquaculture, additional research is required to compare its toxicity to different salmon species and age classes of salmon at a variety of temperatures.

In our study, the gills of Atlantic and chinook salmon from the treatment groups that suffered high mortalities were characterized by extensive regions of epithelial lifting, tissue necrosis, and congestion of the primary and secondary lamellae. Thomassen (1993) investigated the sublethal effects of exposure to hydrogen peroxide on the structure of the gill, cornea and oesophagus of Atlantic salmon. At a water temperature of $6.0^{\circ} \mathrm{C}$, exposure to concentrations of 1.8 and $3.7 \mathrm{~g} \mathrm{l}^{-1}$ for $30 \mathrm{~min}$ and $1.6 \mathrm{~g} \mathrm{l}^{-1}$ for $60 \mathrm{~min}$ resulted in no significant effects on gill structure. Exposure to a concentration of $10.0 \mathrm{~g} \mathrm{l}^{-1}$ for $30 \mathrm{~min}$ resulted in severe gill damage characterized by extensive desquamation (lifting) of the gill epithelium in $25 \%$ of the fish. No effects on the structure of the cornea or on oesophagus structure were evident from any of the treatments.

Extensive lifting of the gill epithelium and necrosis was report in Oreochromis niloticus fry exposed to 0.24 to $0.48 \mathrm{~g} \mathrm{l}^{-1}$ hydrogen peroxide at $30^{\circ} \mathrm{C}$ (Innes Taylor $\&$ Ross 1988). At lower concentrations (0.03 and $0.06 \mathrm{~g}$ $\left.\mathrm{l}^{-1}\right)$, they reported no lifting of the gill epithelium, but extensive telangiectasis as well as some swelling and fragmentation of the epithelial nuclei occurred. 
The subacute effects of hydrogen peroxide to salmonids after single and repeated treatments remains to be determined. It is well recognized that hydroxyl radicals, which can be generated from hydrogen peroxide can cause peroxidation of lipids in cellular and organellar membranes, cross-linking of proteins leading to enzyme inactivation, and derangements as well as inactivation of DNA replication (Cotran et al. 1989). Their effects on the membranes of the gill epithelium and blood cells, and their physiological functions, remain to be determined. It is also possible that hydrogen peroxide treatments may result in increased levels of stress, and the possibility of secondary disease outbreaks, in treated fish.

In summary, a $20 \mathrm{~min}$ exposure to hydrogen peroxidc at a concontration of $1.5 \mathrm{~g}^{1^{-1}}$ effectively removes a high proportion of the preadult and adult stages of Lepeophtheirus salmonis. The lack of efficacy against the chalimus stages as well as the lack of protection against reinfection will necessitate frequent treatments to maintain acceptable low levels of $L$. salmonis. However, the reduced development of eggs treated with hydrogen peroxide may reduce the rate at which treated stocks become reinfected. Atlantic salmon are less sensitive to hydrogen peroxide than chinook salmon. The toxicity to both salmon species increases with increasing water temperatures, concentration and exposure time. At lethal doses histological examination of gills of both salmon species showed extensive epithelial lifting and necrosis. If hydrogen peroxide is to be used as a therapeutant for fish its sublethal effects on the structure and function of the gill epithelium and on the blood, as well as the posttreatment levels of stress in treated fish, will require further study.

Acknowledgements. We thank Drs L. Margolis and T. Evelyn for critically reviewing our manuscript. This research was funded by the Department of Fisheries and Ocean's Biological Sciences Branch. Pacific Region, and by the British Columbia Salmon Farmers Association. S.C.J. was supported by a Natural Sciences and Engineering Research Council of Canada Postdoctoral Fellowship.

\section{LITERATURE CITED}

Brandal, P. O., Egidius, E. (1979). Treatment of salmon lice (Lepeophtheirus salmonis Kroyer, 1838) with Neguvon description of method and equipment. Aquaculture 18: 183-188

Bron, J. E., Sommerville, C., Rae, G. H. (1993). The functional morphology of the alimentary canal of larval stages of the parasitic copepod Lepeophtheirus salmonis. J. Zool., Lond. 230: $207-220$

Bruno, D. W. (1992). The use of hydrogen peroxide $\left(\mathrm{H}_{2} \mathrm{O}_{2}\right)$ to remove sea lice from farmed Atlantic salmon. First European Crustacean Conference Abstracts, Paris, France, Aug. 31 - Sept. 5, 1992. Paris, p. 18

Bruno, D. W., Stone, J. (1990). The role of saithe, Pollachius vrens L., as a host for Lepeophtheirus salmonis Krøyer and Caligus elongatus Nordmann. Aquaculture 89: 201-207

Cotran, R. S., Kumar, V., Robbins, S. L. (1989), Robbins pathological basis of disease, 4th edn. W. B. Saunders Co., Toronto

Grave, K., Engelstad, M., Soli, N. F. (1991a). Utilization of dichlorvos and trichlorfon in salmonid farming in Norway during 1981-1988. Acta vet. scand. 32:1-7

Grave, K., Engelstad, M., Seli, N. F., Toverud, E.-L. (1991b) Clinical use of dichlorvos (Nuvan) and trichlorfon (Neguvon) in the treatment of the salmon louse, Lepeophtheirus salmonis. Compliance with the recommended treatment procedures. Acta. vet. scand. 32: 9-14

Innes Taylor, N., Ross, L. G. (1988). The use of hydrogen peroxide as a source of oxygren for the transportation of live fish. Aquaculture 70: 183-192

Jackson, D., Costello, M. J. (1992). Dichlorvos and alternative sea lice treatments. In: De Pauw. N., Joyce, J. (eds.) Aquaculture and the environment, 1991. Spec. Publs Eur. Aquacult. Soc. 16: 215-221

Johnson, S. C., Albright, L. J. (1991). Development, growth, and survival of Lepeophtheirus salmonis (Copepoda: Caligidae) under laboratory conditions. J. mar. biol. Ass U.K. $71: 425-436$

Johnson, S. C., Kent, M. (1992). Sea lice. In: Kent, M. (ed.) Diseases of seawater netpen-reared salmonid fishes in the Pacific Northwest. Can. Spec. Publ. Fish. Aquat. Sci. 116 $50-55$

Jones, M. W., Sommerville, C., Wootten, R. (1992). Reduced sensitivity of the salmon louse, Lepeophtheirus salmonis, to the organophosphate dichlorvos. J. Fish Dis. 15 $197-202$

Kabata, Z. (1985). Parasites and disease of fish cultured in the tropics. Taylor and Francis, London

Pike, A. W. (1989). Sea lice - major pathogens of farmed Atlantic salmon. Parasitol. Today 5: 291-297

Powell, M. D., Speare, D. J., Burka, J. F. (1992). Fixation of mucus on rainbow trout (Oncorhynchus mykiss Walbaum) gills for light and electron microscopy. J. Fish Biol. 41: 813-824

Roth, M., Richards, R. H., Sommerville, C. (1993). Current practices in the chemotherapeutic control of sea lice infestations in aquaculture. J. Fish Dis. 16: 1-26

Schäperclaus, W. (1989). Fish diseases. Amerind Publishing Co., New Delhi (translated from German: Fischkrankheiten. Akademie-Verlag, Berlin, 1986)

Sokal, R. R., Rohlf, F. L. (1981). Biometry. W. H. Freeman and Company, New York

Thomassen. J. M. (1993). Hydrogen peroxide as a delousing agent for Atlantic salmon. In: Boxshall, G. A., DeFaye, D. (eds.) Pathogens of wild and farmed fish: sea lice. Ellis Horwood, Chichester, p. 290-295

Vosel, A. I. (1965). Quantitative inorganic analysis. Longhams, Green \& Co., New York

Wootten, R., Smith. J. W., Needham, E. A. (1982). Aspects of the biology of the parasitic copepods Lepeophtheirus salmonis and Caligus elongatus on farmed salmonids, and their treatment. Proc. R. Soc. Edinb. Sect. B. (Biol.) 81. 185- 197 